Amino acids

cortisol

fat feeding

glucagon

gluconeogenesis glucose utilization insulin

Ketone bodies newborn

\title{
Influence of Exogenous Cortisol and Triglyceride Feeding on Glucose Homeostasis in the Fasted Newborn Rat
}

\author{
PASCAL FERRE, JEAN-PAUL PEGORIER, ROGER ASSAN, ERROL B. MARLISS, AND JEAN \\ GIRARD $^{(58)}$ \\ Laboratoire de Physiologie du Développement, Collège de France (P.F., J.-P.P., J.G.); Laboratoire de Diabétologie, \\ Hôtel Dieu (R.A.), Paris, France; and Department of Medicine, University of Toronto, Toronto, Canada (E.B.M.)
}

\begin{abstract}
Summary
The effects of cortisol injection $(0.2 \mathrm{mg} / \mathrm{g}$ body wt) at birth and of triglyceride feeding $(20 \mathrm{mg} / \mathrm{g}$ body wt) $13 \mathrm{hr}$ after birth have been studied in 16-hr-old fasted newborn rats. Cortisol produced a $10 \%$ decrease in body weight and in protein concentrations of carcass, hindlimb muscle, and liver. Furthermore, cortisol induced a $60 \%$ fall in carcass lipid levels. Cortisol caused a 2-fold increase in fasting blood glucose level. This effect resulted from a stimulation of gluconeogenesis (as shown by the 2- to 3-fold rise in the rate of conversion of labeled lactate or alanine to glucose). Several factors influenced this response: 1) increase in circulating gluconeogenic substrates (lactate, pyruvate, alanine, proline, and glutamine), 2) increase in plasma glucagon, 3) a small rise in plasma free fatty acids (FFA) arising from the catabolism of endogenous lipids, thereby providing additional energy for the hepatic conversion of gluconeogenic substrates to glucose. A concurrent decrease in glucose utilization was unlikely since: 1 ) the rate of glucose disappearance after an ip glucose load was similar in fasted and cortisol-treated newborns, and 2) the rise in plasma insulin occurring after cortisol injection would ordinarily tend to increase glucose utilization.

Triglyceride feeding was associated with a 2-fold rise in fasting blood glucose. This effect was secondary to a stimulation of gluconeogenesis by provision of free FFA, as demonstrated by the 2.5-fold increase in the conversion in vivo of labeled lactate and alanine into glucose.

In newborn rats injected with cortisol, the levels of both plasma FFA and blood ketone bodies remained far below those in suckling newborns of the same age. The combination of cortisol injection at birth with triglyceride feeding $13 \mathrm{hr}$ after birth caused a 3-fold increase in blood glucose levels in the 16-hr-old newborn rats. The stimulating effects of cortisol on gluconeogenesis were potentiated by triglyceride feeding, as shown by the 3-to 4-fold increase in the rate of lactate or alanine conversion to glucose. However, cortisol markedly decreased the ketosis induced by triglyceride feeding and increased plasma triglycerides.
\end{abstract}

\section{Speculation}

Corticosteroids have been used in the treatment of symptomatic hypoglycemia in newborn infants. In fasted newborn rats, cortisol partially prevents hypoglycemia, but at the cost of increased protein catabolism. Moreover, cortisol has an antiketogenic effect, thus decreasing the availability of ketones as alternate fuel for brain metabolism and as precursor for brain lipid synthesis. If such data can be extrapolated to the human newborn, the prolonged use of corticosteroids in the treatment of neonatal hypoglycemia seems less physiologic than adequate parenteral energy substrate provision in the form of intralipid and gluconeogenic precursors (lactate, amino acids, and glycerol).
Profound hypoglycemia has been shown to occur in newborn rats after a fast of 16-24 hr beginning at birth $(5,17,19)$. This hypoglycemia resulted from an inadequate rate of gluconeogenesis (19) secondary to a deficiency of gluconeogenic substrates $(17,19)$ and FFA $(13,19)$. Newborn rats are unusual in not having fat stores available for endogenous provision of free fatty acid during fasting. They have no white adipose tissue (23), and the small amount of lipids stored in the brown adipose tissue is not mobilizable during fasting at thermoneutral temperature (26).

As such, they are analogous to the premature or small for gestational age newborns which have deficient fat stores and frequently develop neonatal hypoglycemia $(4,5)$. Corticosteroid therapy has been used successfully in these and other forms of hypoglycemia (4). The rationale behind this treatment is to use corticosteroids in pharmacologic doses for increasing amino acid mobilization from muscle, thereby stimulating gluconeogenesis, and for induction of appropriate enzyme activities. The present study was performed to analyze the effects of cortisol on glucose homeostasis in fasted newborn rats. Since triglyceride is the principal energy source in rat milk and is necessary to support the enhanced gluconeogenic rate in suckling rat $(12,14,41)$, the effect of cortisol in combination with exogenous triglyceride was also studied.

\section{MATERIALS AND METHODS}

Newborn Wistar rats were delivered by cesarean section at $18.00 \mathrm{hr}$ at 21.5 days of gestation, normal gestation being 22 days. Timing of gestation was as previously described (17). The newborns were transferred to a Humidicrib (Jouan S.A., Paris, France) in which temperature was kept constant at $37^{\circ}$ and relative humidity at $70 \%$. Enzymes and coenzymes were supplied by Boehringer Corp., Paris, France.

\section{EXPERIMENTAL PROCEDURES}

Cortisol Injection. A group of newborn rats was injected sc immediately after delivery with $0.2 \mathrm{mg} / \mathrm{g}$ body wt of a suspension of hydrocortisone acetate (Acetate d'hydrocortisone, Roussel, Paris) in a volume of $50 \mu \mathrm{l}$, and the newborns were studied $16 \mathrm{hr}$ after birth.

Triglyceride Feeding. A group of fasted newborn rats was allowed to suckle, by using a small rubber teat, $20 \mathrm{mg} / \mathrm{g}$ body wt of a triglyceride emulsion (54) $13 \mathrm{hr}$ after birth and was immediately placed back in the Humidicrib for $3 \mathrm{hr}$, then studied.

Cortisol Injection and Triglyceride Feeding. Another group of newborn rats received an injection of $0.2 \mathrm{mg} / \mathrm{g}$ body wt of hydrocortisone acetate at delivery and was fed with $20 \mathrm{mg} / \mathrm{g}$ body wt of triglyceride emulsion at $13 \mathrm{hr}$ and was studied at $16 \mathrm{hr}$.

Controls. Since it has been previously shown that $0.9 \% \mathrm{NaCl}$ ( $\mathrm{w} / \mathrm{v})$ feeding $(20 \mathrm{mg} / \mathrm{g}$ body wt) at $13 \mathrm{hr}$ did not modify any of 
the measured metabolites or hormones at $16 \mathrm{hr}(13,14)$, control rats used in the present experiments received only a sc injection of $50 \mu \mathrm{l} \mathrm{NaCl} 0.9 \%$ (w/v) at delivery.

Estimation of Rate of Gluconeogenesis in Vivo. Groups of newborn rats treated as described above were injected ip with labeled precursor $\left(0.2 \mu \mathrm{Ci} / \mathrm{g}\right.$ body wt of $\left[U_{-}{ }^{14} \mathrm{C}\right]$ lactate (Amersham, Bucks, U.K.) or $0.2 \mu \mathrm{Ci} / \mathrm{g}$ body wt $\left[U_{-}{ }^{14} \mathrm{C}\right]$ alanine (Centre de l'Energie Atomique, Saclay, France) $16 \mathrm{hr}$ after birth and blood was sampled 30 min later as described previously $(18,19)$.

Glucose Tolerance Test. Groups of fasted and cortisol-treated newborn rats were injected ip with D-glucose at a dose of $2 \mathrm{mg} / \mathrm{g}$ body wt $13 \mathrm{hr}$ after birth and blood was sampled 30,60,120, and $180 \mathrm{~min}$ later. The rate of glucose disappearance $(\mathrm{K})$ was calculated as follows:

$$
K=\frac{2.03\left(\log G_{1}-\log G_{2}\right)}{\left(t_{2}-t_{1}\right)}
$$

and expressed in percentage per min. $G_{1}$ and $G_{2}$ represent blood glucose concentration at time $t_{1}$ and $t_{2}$.

Blood Sampling and Analytic Methods. The technique for blood sampling and the biochemical methods used for metabolite, amino acid, and hormone determinations were as described previously (17-19). Enzymatic techniques were used for the determination of lactate (38), pyruvate (39), glycerol (49), alanine (50), 3-hydroxybutyrate (33), acetoacetate (34), and glucose (2) on blood perchloric acid filtrates. Plasma free fatty acids were determined using a radiochemical assay (25) with ${ }^{63} \mathrm{Ni}$ as tracer (Centre de l'Energie Atomique, Saclay, France). An automated ion-exchange chromatographic technique on Beckman $120 \mathrm{C}$ amino acid analyzer with lithium buffer system was used for the determination of individual amino acids on blood sulfosalicylic filtrates (27). Triglycerides in plasma or tissues were extracted by the method of Folch et al. (15) and their glycerol content was determined after ethanolic-alkaline hydrolysis (30). In some experiments, hindlimb muscles, liver, interscapular brown adipose tissue, and carcass (i.e., whole body minus viscera) were obtained and frozen in liquid nitrogen immediately after blood sampling. Liver, muscle, and carcass glycogen were determined by using the enzymatic technique with amyloglucosidase (EC 3.2.1.33) as described by Roehrig and Allred (44). Lipids in the carcass were measured as described by Folch et al. (15). Proteins were precipitated with $10 \%$ $(w / v)$ trichloracetic acid. The precipitate thus obtained was dissolved in $1 \mathrm{~N} \mathrm{NaOH}$ and an aliquot was analyzed for its protein content (20).

Insulin and glucagon were determined by radioimmunoassays $(1,28)$. Glucagon was assayed using antibody $30 \mathrm{~K}$ (supplied by Dr. R. H. Unger, Dallas, TX) and purified pork glucagon as standard (Novo Industry SA, Copenhagen, Denmark) and tracer (Centre National de la Transfusion Sanguine, Paris, France). Insulin was assayed using a guinea pig antibody reacting poorly with proinsulin, human insulin as tracer (Centre National de la Transfusion Sanguine) and purified rat insulin as standard (Novo Industry SA).

Measurement of gluconeogenic rate in vivo was performed as described previously $(12,18,19)$ using lactate space equal to the total body water, i.e., $80 \mathrm{mg} / 100 \mathrm{~g}$ body wt, and glucose and alanine spaces equal to the extracellular water, i.e., $60 \mathrm{ml} / 100 \mathrm{~g}$ body wt. The validity of this method has been discussed previously $(18,19)$. The separation of labeled glucose and charged compounds was' performed using ion-exchange resins as described previously (12).

Results are expressed as mean \pm SEM. Statistical analyses were performed using the Student unpaired $t$-test, to establish the significance of changes between control and experimental groups.

\section{RESULTS}

EFFECTS OF CORTISOL ON BODY WEIGHT AND ON COMPOSITION OF CARCASS, LIVER, SKELETAL MUSCLE, AND BROWN ADIPOSE TISSUE OF FASTED NEWBORN RATS

A fast of $16 \mathrm{hr}$ in a thermoneutral environment produced a $10 \%$ decrease in body weight of newborn rats (Table 1). This was
Table 1. Effects of fasting and cortisol on body weight and energy stores of newborn rats ${ }^{1}$

\begin{tabular}{|c|c|c|c|}
\hline & \multirow[b]{2}{*}{$\begin{array}{l}\text { At birth } \\
(6)\end{array}$} & \multicolumn{2}{|c|}{$16 \mathrm{hr}$ after birth } \\
\hline & & $\begin{array}{l}\text { Fasted } \\
\text { controls } \\
(6)\end{array}$ & $\begin{array}{l}\text { Fasted }+ \\
\text { cortisol } \\
(6) \\
\end{array}$ \\
\hline Body wt (g) & $5.1 \pm 0.1$ & $4.6 \pm 0.1^{2}$ & $4.1 \pm 0.1^{2,3}$ \\
\hline \multicolumn{4}{|l|}{$\begin{array}{r}\text { Carcass composition } \\
(\mathrm{mg} / \mathrm{g} \text { fresh } w \mathrm{t})\end{array}$} \\
\hline Lipids & $27 \pm 2$ & $24 \pm 3$ & $10 \pm 1^{2,3}$ \\
\hline Proteins & $95 \pm 1$ & $82 \pm 3^{2}$ & $72 \pm 3^{2,3}$ \\
\hline Glycogen & $2.4 \pm 0.2$ & $0.90 \pm 0.10^{2}$ & $0.98 \pm 0.10^{2}$ \\
\hline \multicolumn{4}{|l|}{$\begin{array}{l}\text { Liver composition (mg/g } \\
\text { fresh wt) }\end{array}$} \\
\hline Triglycerides & $2.2 \pm 0.1$ & $1.1 \pm 0.2^{2}$ & $1.6 \pm 0.2^{2,3}$ \\
\hline Proteins & $164 \pm 11$ & $155 \pm 3$ & $123 \pm 7^{2,3}$ \\
\hline Glycogen & $97 \pm 8$ & $0.7 \pm 0.1^{2}$ & $0.8 \pm 0.1^{2}$ \\
\hline \multicolumn{4}{|l|}{$\begin{array}{l}\text { Hindlimb muscle compo- } \\
\text { sition ( } \mathrm{mg} / \mathrm{g} \text { fresh wt) }\end{array}$} \\
\hline $\begin{array}{l}\text { Proteins } \\
\text { Glycogen }\end{array}$ & $77 \pm 2$ & $70 \pm 3^{2}$ & $53 \pm 3^{2,3}$ \\
\hline Glycogen & $5.8 \pm 0.1$ & $1.8 \pm 0.1^{2}$ & $2.1 \pm 0.3^{2}$ \\
\hline $\begin{array}{l}\text { Brown adipose tissue: tri- } \\
\text { glycerides (mg/g fresh } \\
\text { wt) }\end{array}$ & $37 \pm 6$ & $30 \pm 5$ & $33 \pm 4$ \\
\hline
\end{tabular}

\footnotetext{
${ }^{1}$ Values are means \pm SEM of the number of observations shown in parentheses.

${ }^{2} P<0.05$ when compared with pups at birth.

${ }^{3} P<0.05$ when compared with 16 -hr fasted controls.
}

associated with a marked fall in carcass, skeletal muscle, and liver glycogen levels and with a $10 \%$ decrease in carcass and skeletal muscle protein concentrations (Table 1). The liver proteins were not decreased by fasting. The concentrations of lipids in the carcass and of triglycerides in the brown adipose tissue were not decreased by fasting in a thermoneutral environment. By contrast, fasting induced a $50 \%$ fall in liver triglyceride levels (Table 1).

Cortisol injection at birth caused a further decrease in body weight of fasted newborn rats (table 1). When compared with fasted newborns, the fasted pups injected with cortisol showed a $10 \%$ decrease in carcass, skeletal muscle, and liver protein concentrations and a 60\% fall in carcass lipid levels (table 1). Cortisol injection caused a significant increase in liver triglyceride concentration in fasted newborns (Table 1).

\section{EFFECTS OF CORTISOL, TRIGLYCERIDE FEEDING, AND CORTISOL IN COMBINATION WITH TRIGLYCERIDE FEEDING ON} CIRCULATING BLOOD SUBSTRATES AND HORMONES

Cortisol injection at birth produced a 2 -fold increase in blood glucose level, compared with fasted controls (Table 2). This was associated with a rise in both plasma insulin and glucagon (Table 2). Concurrently, cortisol administration was associated with a marked increase in gluconeogenic substrates as compared to 16$\mathrm{hr}$-old fasted newborn rats. An increase in lactate, pyruvate (Table $2)$, glutamine, proline, and alanine as well as in tyrosine, citrulline, and ornithine (Table 3 ) was observed. Cortisol also induced a 2 fold increase in plasma FFA and blood ketone bodies (Table 2).

As previously reported $(13,14)$, triglyceride feeding alone produced a 2 -fold increase in blood glucose (Table 2) and was associated with a 7-fold increase of blood ketones, a 3-fold increasc of FFA, and a modest but significant rise in triglycerides, glyceroi, lactate, and pyruvate. Plasma insulin increased after triglyceride feeding but glucagon remained unchanged (Table 2). Significant increases in blood glutamine, proline, alanine, and isoleucine were also observed in triglyceride-fed newborn rats (Table 3).

A combination of cortisol injection at birth and triglyceride feeding $13 \mathrm{hr}$ after birth resulted in a 3 -fold increase in blood glucose level in 16-hr-old newborn rats (Table 2). The levels of gluconeogenic substrates and of insulin and glucagon were the same in newborns injected with cortisol alone and those injected 
Table 2. Effects of cortisol, triglyceride feeding, and cortisol plus triglyceride feeding on circulating substrates (millimoles per liter) and hormones in newborn rats 1

\begin{tabular}{|c|c|c|c|c|}
\hline & $\begin{array}{c}\text { Fasted controls } \\
\text { (25) }\end{array}$ & $\begin{array}{l}\text { Cortisol } \\
\text { (28) }\end{array}$ & $\begin{array}{l}\text { Triglyceride fed } \\
\qquad(30)\end{array}$ & $\begin{array}{c}\text { Cortisol }+ \\
\text { triglyceride fed } \\
(31)\end{array}$ \\
\hline Blood glucose & $1.05 \pm 0.12$ & $1.94 \pm 0.15^{2}$ & $2.01 \pm 0.15^{2}$ & $2.95 \pm 0.12^{2-4}$ \\
\hline Blood lactate & $0.82 \pm 0.05$ & $1.58 \pm 0.13^{2}$ & $1.01 \pm 0.04^{2}$ & $1.84 \pm 0.17^{2,4}$ \\
\hline Blood pyruvate & $0.046 \pm 0.005$ & $0.074 \pm 0.004^{2}$ & $0.086 \pm 0.009^{2}$ & $0.084 \pm 0.004^{2}$ \\
\hline Blood glycerol & $0.129 \pm 0.006$ & $0.149 \pm 0.005^{2}$ & $0.144 \pm 0.017^{2}$ & $0.170 \pm 0.001^{2-4}$ \\
\hline Plasma FFA & $0.233 \pm 0.027$ & $0.526 \pm 0.053^{2}$ & $0.635 \pm 0.070^{2}$ & $0.860 \pm 0.015^{2-4}$ \\
\hline Plasma triglycerides & $0.42 \pm 0.04$ & $0.49 \pm 0.03$ & $0.57 \pm 0.05^{2}$ & $1.17 \pm 0.06^{2-4}$ \\
\hline Blood 3-hydroxybutyrate & $0.197 \pm 0.014$ & $0.490 \pm 0.050^{2}$ & $1.42 \pm 0.28^{2}$ & $1.10 \pm 0.10^{2-4}$ \\
\hline Blood acetoacetate & $0.074 \pm 0.007$ & $0.090 \pm 0.010$ & $0.51 \pm 0.04^{2}$ & $0.14 \pm 0.01^{2-4}$ \\
\hline Total blood ketone bodies & $0.27 \pm 0.02$ & $0.58 \pm 0.06^{2}$ & $1.93 \pm 0.3^{2}$ & $1.24 \pm 0.1^{2-4}$ \\
\hline Plasma insulin $(\mu \mathrm{U} / \mathrm{ml})$ & $11 \pm 2$ & $19 \pm 0.5^{2}$ & $21 \pm 2^{2}$ & $22 \pm 1^{2}$ \\
\hline Plasma glucagon $(\mathrm{pg} / \mathrm{ml})$ & $900 \pm 60$ & $1337 \pm 67^{2}$ & $992 \pm 90$ & $1373 \pm 113^{2.4}$ \\
\hline
\end{tabular}

1 Values are means \pm SEM of the number of observations shown in parentheses.

${ }^{2} P<0.05$ when compared with fasted controls.

${ }^{3} P<0.05$ when compared with cortisol.

${ }^{4} P<0.05$ when compared with triglyceride fed.

Table 3. Effects of cortisol, triglyceride feeding, and cortisol plus triglyceride feeding on blood amino acids (micromoles per liter) in newborn rats ${ }^{1}$

\begin{tabular}{lcccc}
\hline & $\begin{array}{c}\text { Fasted } \\
\text { controls }\end{array}$ & $\begin{array}{c}\text { Cortisol } \\
(4)\end{array}$ & $\begin{array}{c}\text { Trigly- } \\
\text { ceride fed } \\
(4)\end{array}$ & $\begin{array}{c}\text { Cortisol + } \\
\text { triglyceride } \\
\text { fed } \\
(4)\end{array}$ \\
\hline Taurine & $727 \pm 108$ & $808 \pm 112$ & $774 \pm 11$ & $880 \pm 28$ \\
Aspartic acid & $84 \pm 10$ & $96 \pm 3^{2}$ & $63 \pm 4^{3}$ & $91 \pm 10$ \\
Threonine & $180 \pm 20$ & $199 \pm 12$ & $182 \pm 10$ & $206 \pm 9$ \\
Serine & $204 \pm 22$ & $241 \pm 13$ & $197 \pm 8$ & $250 \pm 13$ \\
Asparagine & $96 \pm 12$ & $100 \pm 9$ & $105 \pm 5$ & $134 \pm 6^{2-4}$ \\
Glutamine & $659 \pm 63$ & $1637 \pm 105^{2,4}$ & $904 \pm 81^{3,4}$ & $1497 \pm 104^{2,4}$ \\
Proline & $90 \pm 10$ & $229 \pm 37^{2,4}$ & $140 \pm 17^{3,4}$ & $204 \pm 54^{4}$ \\
Glutamic acid & $186 \pm 23$ & $189 \pm 15$ & $218 \pm 11$ & $283 \pm 17^{2-4}$ \\
Citrulline & $105 \pm 20$ & $155 \pm 16^{2,4}$ & $77 \pm 6^{3}$ & $95 \pm 6^{2,3}$ \\
Glycine & $821 \pm 88$ & $986 \pm 97$ & $783 \pm 44$ & $877 \pm 66$ \\
Alanine & $206 \pm 17$ & $353 \pm 27^{4}$ & $422 \pm 38^{4}$ & $450 \pm 30^{3,4}$ \\
Valine & $307 \pm 28$ & $385 \pm 8$ & $339 \pm 26$ & $313 \pm 30^{3}$ \\
Isoleucine & $95 \pm 2$ & $104 \pm 6^{2}$ & $146 \pm 5^{3,4}$ & $112 \pm 10^{2}$ \\
Leucine & $196 \pm 7$ & $216 \pm 12$ & $225 \pm 11$ & $192 \pm 12$ \\
Tyrosine & $98 \pm 27$ & $165 \pm 12^{4}$ & $154 \pm 5^{4}$ & $156 \pm 6^{4}$ \\
Phenylalanine & $60 \pm 13$ & $68 \pm 2$ & $72 \pm 4$ & $81 \pm 3$ \\
Ornithine & $62 \pm 6$ & $98 \pm 6^{4}$ & $88 \pm 5$ & $84 \pm 7$ \\
Lysine & $746 \pm 184$ & $623 \pm 93$ & $781 \pm 87$ & $509 \pm 65^{2,3}$ \\
Histidine & $155 \pm 34$ & $253 \pm 31^{2}$ & $190 \pm 25^{3}$ & $225 \pm 15$ \\
Arginine & $145 \pm 31$ & $201 \pm 66^{2}$ & $124 \pm 3^{3}$ & $107 \pm 9^{3}$ \\
\hline
\end{tabular}

${ }^{1}$ Values are means \pm SEM of the number of observations shown in parentheses. For alanine, the number of determinations is $25-31$ and determinations were performed by an enzymatic fluorimetric technique (9).

${ }^{2} P<0.05$ when compared with triglyceride fed.

${ }^{3} P<0.05$ when compared with cortisol.

${ }^{4} P<0.05$ when compared with the fasted controls.

with cortisol and fed with triglycerides (Tables 2 and 3). Plasma FFA and triglycerides and blood ketone bodies were higher in newborns injected with cortisol and fed with triglycerides than in newborns injected with cortisol alone. Cortisol decreased the rise in blood ketone body concentration induced by triglyceride feeding and it increased the plasma triglyceride levels.

\section{EFFECTS OF CORTISOL ON GLUCOSE TOLERANCE}

In order to test for a possible decrease in glucose utilization after cortisol treatment, the glucose tolerance test was performed in fasted and cortisol-treated newborn rats. The results are shown in Figure 1. Although the peak in blood glucose was slightly

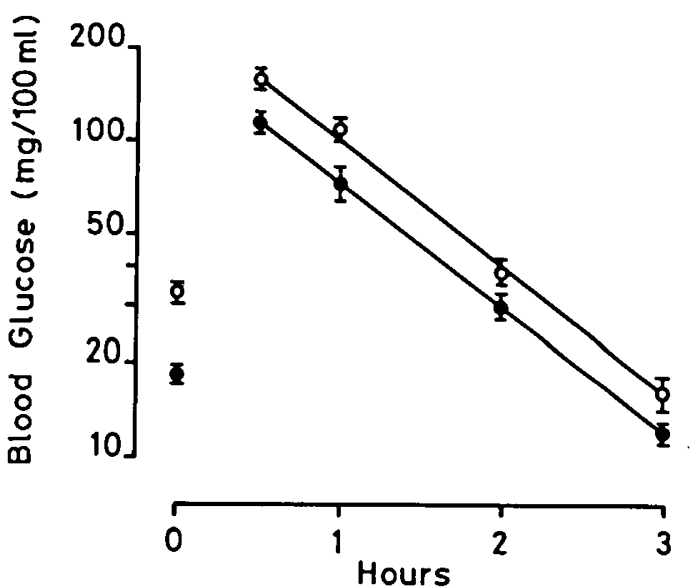

Fig. 1. Semilogarithmic graph of blood glucose concentration after ip injection of $2 \mathrm{mg}$ glucose/g body wt in fasted and cortisol-injected newborn rats. Fasted newborn rats were injected sc with $0.9 \% \mathrm{NaCl}$ or with cortisol $(0.2 \mathrm{mg} / \mathrm{g}$ body $\mathrm{wt})$ immediately after birth, and injected with glucose 13 hr after birth. $\longrightarrow$, fasted controls; $\mathrm{O}-\mathrm{O}$, cortisol treated. A total of 60 pups were used for each glucose tolerance test. Each point is the mean \pm SEM of a group of 12 different newborns.

higher in cortisol-treated group than in the fasted group, there was no alteration in glucose tolerance demonstrable by this technique in newborns injected with cortisol. The calculated rate of glucose disappearance was (in percentage per min): 1.31 in fasted controls and 1.35 in cortisol-injected newborns. Using the same glucose tolerance test, it was previously observed that triglyceride feeding alone did not modify the rate of glucose disappearance: $1.4 \% / \mathrm{min}$ in fasted controls and $1.5 \% / \mathrm{min}$ in triglyceride-fed newborns (14).

\section{EFFECTS OF CORTISOL AND CORTISOL PLUS TRIGLYCERIDE FEEDING ON GLUCONEOGENESIS}

Cortisol injection at birth increased the rate of gluconeogenesis from lactate and alanine 2- to 3 -fold by $16 \mathrm{hr}$ (Table 4). Triglyceride feeding at $13 \mathrm{hr}$ increased gluconeogenesis from lactate and alanine 2.5-fold. The combination of cortisol injection at birth and triglyceride feeding at $13 \mathrm{hr}$ increased by 3 - to 4 -fold the rate of gluconeogenesis from lactate and alanine, when compared to fasted controls. However, only the rate with lactate as substrate was significantly greater with combined treatment than with cortisol alone.

These increases resulted from both an increased pool size of precursor and an increased conversion of labeled substrate into glucose. The latter effect may be linked in part to the rise in 
plasma glucagon (Table 2), although the levels in fasted controls are already markedly elevated.

The specific radioactivity of precursor at the time of sampling was, respectively: 10,15 , and $20 \%$ lower in cortisol, triglyceridefed, and cortisol plus triglyceride-fed newborns than in fasted newborns. This caused a small underestimation of the effect of cortisol, triglyceride feeding, and cortisol plus triglyceride feeding in those experiments.

\section{DISCUSSION}

The aims of the present work were to use exogenous cortisol in pharmacologic doses as a mean of protecting the newborn rat from developing hypoglycemia when fasted at birth, and to examine the mechanisms of these effects. It is recognized that this approach does not necessarily provide the evidence that the postnatal increase in plasma corticosterone (8) plays a physiologic role in neonatal metabolic adaptations.

The hypoglycemia which develops in fasted newborn rats is partially reversed by giving cortisol alone but is better prevented by the combination of cortisol and oral triglycerides (Table 2). These findings are paralleled by previous observations showing that oral triglyceride or exogenous gluconeogenic substrate injection individually, only partially reversed neonatal fasting hypoglycemia, but that the combination of oral triglyceride with exogenous gluconeogenic substrate injection completely reversed this hypoglycemia $(13,14)$, with reference to normally suckling pups $(12,19,41)$.

These data clearly show that lack of gluconeogenic substrates is not the only factor limiting the activity of gluconeogenesis in fasted newborn rats. Since the effect of increased gluconeogenic substrate on glycemia is markedly potentiated by fat feeding, both FFA availability and hepatic fatty acid oxidation are essential to sustain a high rate of hepatic gluconeogenesis.

\section{EFFECTS OF CORTISOL}

Two mechanisms may explain the rise in blood glucose after cortisol injection in fasted newborn rats. 1) A decrease in glucose utilization is possible, secondary to the rise in plasma FFA and ketone bodies (42) or to a direct effect of cortisol on glucose uptake in several tissues (36). 2) A stimulation of gluconeogenesis is probable, secondary to increased provision of gluconeogenic substrates and of ATP, NADH, and acetyl-CoA, via increased plasma FFA and/or to an increase of hepatic enzyme activities. Several lines of evidence render unlikely that a decreased utilization of glucose is responsible for the rise in blood glucose after cortisol injection: a) the rate of glucose disappearance after an ip glucose load is similar in fasted and cortisol-injected newborn rats, b) the glucose turnover rate, measured using $\left[3-{ }^{3} \mathrm{H}\right]$ glucose, is increased after cortisol injection in fasted newborn rats (Ferré, Pegorier, and Girard, unpublished data), and c) the rise of plasma insulin occurring after cortisol injection would tend to increase rather than decrease glucose utilization.

The present data suggest that cortisol increases blood glucose levels in fasted newborn rats by stimulating gluconeogenesis, through several independent though interacting mechanisms: 1) the increase in circulating gluconeogenic substrates; 2 ) the increase in plasma glucagon; 3 ) the rise in plasma FFA. These factors will be considered and discussed successively.

We have previously reported that cortisol injection at delivery increased blood lactate and caused a generalized and marked hyperaminoacidemia in 4-hr-old fasted newborn rats (18). The present data show that these effects of cortisol are still observed $16 \mathrm{hr}$ after birth, but are of smaller magnitude than at $4 \mathrm{hr}$, and affect only alanine, glutamine, and proline among gluconeogenic amino acids. A likely explanation is that the effects of cortisol are blunted by the rise of plasma amino acids which occurs spontaneously between 6 and $16 \mathrm{hr}$ in fasted newborn rats (19). The increase in blood amino acids produced by cortisol in fasted newborn rats probably results from a stimulation of protein breakdown and/or an inhibition of protein synthesis in peripheral tissues (35), since the weight and protein content of carcass and muscle are decreased in fasted newborn rats injected with cortisol (Table 1). The salutory effect of cortisol on blood glucose levels was obtained at the cost of increased protein utilization, which could result in muscle wasting; this is undesirable for an organism in which continuation of growth is the first priority. The rise in blood lactate observed after corticosteroid injection to fasted newborn rats, or to adult rats treated with phloridzin (31), probably results from a stimulation of lactate production by peripheral tissue greater than the stimulation of hepatic uptake for gluconeogenesis. Lactate could be synthetized from pyruvate, derived from amino acid catabolism or from an increased glycolysis secondarily to the rise in blood glucose and plasma insulin (Table 2).

Cortisol stimulates glucagon secretion in newborn rats even in presence of hyperglycemia (Ref. 18 and the present study). This effect has also been observed in the adult man $(32,52)$ and rat (31). Since exogenous glucagon increases the rate of gluconeogenic substrate conversion to glucose in newborn rats $(18,48)$, the enhanced release of glucagon produced by cortisol probably contributes to its stimulatory effects on neonatal gluconeogenesis.

Cortisol increases plasma FFA in fasted newborn rats, and these FFA appear to arise from the catabolism of lipids of the carcass. Since FFA availability is essential to sustain an active gluconeogenic rate in newborn rats $(13,14)$, a part of the stimulatory effects of cortisol on gluconeogenesis may be secondary to this peripheral lipolytic action.

In adults, glucocorticoids act on hepatic gluconeogenesis by increasing several key gluconeogenic enzymes, i.e., transaminases, pyruvate carboxylase, phosphoenolpyruvate carboxykinase, fructose disphosphatase, glucose-6-phosphatase (reviewed in Refs. 9, 11). However, it is unlikely that these changes entirely account for the effectiveness of the corticosteroids, since gluconeogenic substrate flow to the liver appears to be the dominant rate-limiting factor $(7,16)$. In the present study, such a direct effect on liver enzyme activities has not been investigated. In neonatal rats, cortisol has been shown to increase the activity of alanine aminotransferase (47), but it remained without effect on the activities of pyruvate carboxylase, phosphoenolpyruvate carboxykinase, fructose diphosphatase and glucose-6-phosphatase $(21,53)$. It is unlikely that a direct effect of cortisol on hepatic alanine transaminase can play an important role in the stimulation of gluconeogenesis observed in the present study, since the effect of this hormone is much more marked with lactate as substrate than with alanine as substrate.

\section{EFFECTS OF TRIGLYCERIDE FEEDING}

The mechanisms involved in the rise of blood glucose induced by triglyceride feeding alone have been discussed previously (13, 14). The rise in blood glucose induced by fat feeding was not secondary to a decreased glucose utilization, since the rate of glucose disappearance after ip glucose injection was similar in fasted $\left(1.4 \% \mathrm{~min}^{-1}\right)$ and fat-fed $\left(1.5 \% \mathrm{~min}^{-1}\right)$ newborns (14). Several lines of evidence suggest that fat feeding was associated with stimulation of gluconeogenesis by provision of fatty acids: 1) the rise in blood glucose after fat feeding was totally suppressed by an inhibitor of gluconeogenesis (3-mercaptopicolinate); 2) a 3fold increase in the conversion of labeled lactate or alanine into glucose was observed in vivo after fat feeding, as also reported here in Table 4; and 3) concurrent inhibition of fatty acid oxidation by sodium 4-pentenoate abolished the glycemic rise related to fat feeding (14). Furthermore, inhibition of fatty acid oxidation by sodium 4-pentenoate in suckling newborn rats markedly inhibited gluconeogenesis from lactate and induced a profound hypoglycemia (41). This suggests that adequate hepatic fatty acid oxidation is essential to supply the energy required to sustain a high rate of gluconeogenesis. 
Table 4. Effect of cortisol, triglyceride feeding, and cortisol plus triglyceride feeding on rate of gluconeogenesis measured in vivo from labeled substrates ${ }^{1}$

\begin{tabular}{|c|c|c|c|c|}
\hline Substrate & $\begin{array}{l}\text { Fasted controls } \\
\text { (16) }\end{array}$ & $\begin{array}{c}\text { Cortisol } \\
(15)\end{array}$ & $\begin{array}{c}\text { Triglyceride fed } \\
(6)\end{array}$ & $\begin{array}{c}\text { Cortisol + } \\
\text { triglyceride fed } \\
(10)\end{array}$ \\
\hline \multicolumn{5}{|l|}{ Lactate } \\
\hline Lactate pool $(\mu \mathrm{mol} / 100 \mathrm{~g}$ body wt) & $73.5 \pm 2.1$ & $135.6 \pm 13.3^{2}$ & $112.3 \pm 12.1^{2,3}$ & $165 \pm 17^{2-4}$ \\
\hline$\%$ conversion in $30 \mathrm{~min}$ & $5.6 \pm 0.6$ & $7.2 \pm 0.7^{2}$ & $10.2 \pm 1.1^{2,3}$ & $9.7 \pm 1.8^{2,3}$ \\
\hline $\begin{array}{l}\text { Rate of gluconeogenesis }(\mu \mathrm{mol} / \mathrm{h} / 100 \mathrm{~g} \\
\text { body } \mathrm{wt})\end{array}$ & $4.1 \pm 0.4$ & $9.8 \pm 1.4^{2}$ & $11.4 \pm 1.2^{2}$ & $16 \pm 1.8^{2-4}$ \\
\hline \multicolumn{5}{|l|}{ Alanine } \\
\hline Alanine pool ( $\mu \mathrm{mol} / 100 \mathrm{~g}$ body $\mathrm{wt})$ & $9.2 \pm 0.2$ & $21.7 \pm 1.7^{2,4}$ & $12.1 \pm 1.3^{2,3}$ & $17.3 \pm 0.9^{2-4}$ \\
\hline$\%$ conversion in $30 \mathrm{~min}$ & $2.4 \pm 0.2$ & $4.0 \pm 0.5^{2}$ & $4.6 \pm 0.7^{2}$ & $5.8 \pm 0.5^{2,3}$ \\
\hline $\begin{array}{l}\text { Rate of gluconeogenesis }(\mu \mathrm{mol} / \mathrm{h} / 100 \mathrm{~g} \\
\text { body wt) }\end{array}$ & $0.22 \pm 0.03$ & $0.87 \pm 0.11^{2,4}$ & $0.56 \pm 0.7^{2,3}$ & $1.00 \pm 0.10^{2,4}$ \\
\hline
\end{tabular}

\section{EFFECTS OF CORTISOL IN COMBINATION WITH TRIGLYCERIDE FEEDING}

Although cortisol alone increases the blood glucose and ketone bodies and the plasma FFA in fasted newborn rats, the absolute levels of these substrates remain far below those measured in suckling newborn rats of the same age $(12,19,41)$. Fat feeding was given in combination with cortisol injection to provide these newborns with sufficient fat-derived substrates exogenously.

Triglyceride feeding and cortisol show additive effects on blood glucose levels of fasted newborn rats (Table 2). However, the magnitude of the rise in blood glucose is less marked than in previous experiments in which the effects of triglyceride feeding were associated with injection of exogenous gluconeogenic substrates $(13,14)$. A likely explanation is that cortisol alone not only increases gluconeogenic substrate availability, but also stimulates the mobilization of lipids from the carcass (Table 1), thus providing some FFA to the liver for sustaining the energy-requiring conversion of substrates to glucose. Accordingly, the potentiating effect of exogenous triglycerides is somewhat lessened.

In newborn rats injected with cortisol and fed with triglyceride, the simultaneous decrease in blood ketone bodies and increase in plasma triglycerides suggest that cortisol decreases hepatic fatty acid oxidation rather than it increases ketone body utilization. In adult rats, corticosteroids have been previously shown to prevent the increase in ketone bodies caused by cold exposure (45), fasting $(10,46)$, and phloridzin-treatment $(31)$. They have a similar effect in starved adult man (22) and in children with ketotic hypoglycemia $(3,37)$. Glucocorticoids have been reported to increase plasma triglycerides in adult rats (43) and this has been interpretated as being secondary to the rise in plasma insulin (6), this hormone stimulating hepatic lipogenesis. However, corticosteroids stimulate the release of triglycerides by the isolated perfused rat liver (29) and suckling newborn rats which show a high rate of hepatic ketogenesis have plasma insulin levels higher $(12,19,41)$ than those measured in newborn rats injected with cortisol and fed with triglycerides. This suggests that cortisol could act directly on the liver to channel the flow of FFA towards esterification and thus to decrease fatty acid oxidation and ketogenesis.

The antiketogenic effect of cortisol is particularly undesirable during the neonatal period since the newborn brain metabolizes ketone bodies for energy production, and thus partially reduces glucose requirement for cerebral metabolism (51). Furthermore, it has been recently demonstrated that ketone bodies are better precursors than glucose for lipid synthesis in developing brain (40).

Information gathered from this study of the influence of exogenous cortisol and lipids on glucose homeostasis of the newborn rat may not be directly extrapolated to other mammals, and particularly the human, because of features peculiar to this species: very low body fat content and a high basal metabolic rate. However, such studies may help to understand the mechanisms responsible for the profound hypoglycemia occurring in low birth weight infants which have a low body fat content and an impairment of gluconeogenesis (24).

\section{REFERENCES AND NOTES}

1. Assan, R., Tchobroutsky, G., and Derot, M.; Glucagon radioimmunoassay: Technical problems and recent data. Horm. Metab. Res. (Suppl. 1), 3: 82 (1971).

2. Bergmeyer, H. U., and Bernt, E.: Glucose: Determination with glucose oxidase and peroxidase. In: H. U. Bergmeyer: Methods of Enzymatic Analysis, p. 1205 (Academic Press, New York, 1974).

3. Colle, E., and Ulstrom, R. H.: Ketotic hypoglycemia. J. Pediat., 64 : 632 (1964).

4. Cornblath, M., and Schwartz, R.: Disorders of Carbohydrate Metabolism in Infancy (W. B. Saunders, Philadelphia, 1976).

5. Comblath, M., Tildon, J. T., and Wapnir, R. A.: Metabolic adaptation in the neonate. Israel J. Med. Sci., 8: 453 (1972).

6. Diamant, S., and Shafrir, E.: Modulation of the activity of insulin-dependent enzymes of lipogenesis by glucocorticoids. Eur. J. Biochem., 53: 541 (1975).

7. Dunn, A., Chenoweth, M., and Hemington, J. G.: The relationship of adrenal glucocorticoids to transaminase activity and gluconeogenesis in the intact rat. Biochim. Biophys. Acta, 237: 192 (1971).

8. Eguchi, Y., Arishima, K., Morikawa, Y., and Hashimoto, Y.: Rise of plasma corticosterone concentrations in rats immediately before and after birth and in fetal rats after the ligation of maternal uterine blood vessels or of the umbilical cord. Endocrinology, 100: 1443 (1977).

9. Eisenstein, A.: Effects of adrenal cortical hormones on carbohydrate, protein and fat metabolism. Amer. J. Clin. Nutr., 26: 113 (1973).

10. Engel, M., and Engel, F. L.: Fasting ketosis in the adrenalectomized and cortisone treated rat. Endocrinology, 55: 593 (1954)

11. Exton, J. H.: Gluconeogenesis. Metabolism, 21: 945 (1972).

12. Ferré, P., Pegorier, J. P., and Girard, J.: The effects of inhibition of gluconeogenesis in suckling newborn rats. Biochem. J., 169: 209 (1977).

13. Ferré, P., Pegorier, J. P., Girard, J. R., and Marliss, E. B.: Evidence that fatty acid oxidation stimulates gluconeogenesis in newborn rats. Biochem. Suc. Trans., 5: 982 (1977).

14. Ferré, P., Pegorier, J. P., Marliss, E. B., and Girard, J. R.: Influence of exogenous fat and gluconeogenic substrates on glucose homeostasis in the newborn rat. Amer. J. Physiol., 234: E129-E136 (1978).

15. Folch, J., Lees, M., and Stanley, G. H. S.: A simple method for the isolation and purification of total lipids from animal tissues. J. Biol. Chem., 226: 497 (1957).

16. Friedman, G., Goodman, E. H., and Weinhouse, S.: Dietary and hormonal effects on gluconeogenesis in the rat. J. Biol. Chem., 240: 3729 (1965).

17. Girard, J. R., Cuendet, G. S., Marliss, E. B., Kervran, A., Rieutort, M., and Assan, R.: Fuels, hormones, and liver metabolism at term and during the early postnatal period in the rat. J. Clin. Invest., 52: 3190 (1973).

18. Girard, J. R., Guillet, I., Marty, J., Assan, R., and Marliss, E. B.: Effects of exogenous hormones and glucose on plasma levels and hepatic metabolism of amino acids in the fetus and in the newborn rats. Diabetologia, 12:327 (1976).

19. Girard, J. R., Guillet, I., Marty, J., and Marliss, E. B.: Plasma amino-acid levels and development of hepatic gluconeogenesis in the newborn rat. Amer. J. Physiol., 229: 466 (1975).

20. Gornall, A. G., Bardawill, C. J., and David, M. M.: Determination of serum proteins by means of the biuret reaction. J. Biol. Chem., 177: 751 (1949).

21. Greengard, O.: Cortisol treatment of neonatal rats: Effects on enzyme in kidney, 
liver and heart. Biol. Neonate, 27: 352 (1975).

22. Grey, N. J., Karl, I., and Kipnis, D. H.: Physiologic mechanism in the development of starvation ketosis in man. Diabetes, 24: 10 (1975).

23. Hahn, P., and Novak, M.: Development of brown and white adipose tissue. J. Lipid Res., 16: 79 (1975)

24. Haymond, M. W., Karl, I. E., and Pagliara, A. S.: Increased gluconeogenic substrates in small-for-gestational-age infant. N. Engl. J. Med., 291: 322 (1974).

25. Ho, R. J.: Radiochemical assay of long-chain fatty acid using ${ }^{63} \mathrm{Ni}$ as tracer. Anal. Biochem., 36: 105 (1970).

26. Hull, $\mathrm{D}$, and Hardman, M. J.: Brown adipose tissue in newborn mammals. In: O. Lindberg: Brown Adipose Tissue, p. 97 (Elsevier, New York, 1970).

27. Kadenburg, C. P.: A lithium buffer system for accelerated single column amino acid analysis in physiological fluids. Anal. Biochem., 40:35 (1971).

28. Kervran, A., and Girard, J. R.: Glucose-induced increase of plasma insulin in the rat foetus in utero. J. Endocrinol. 62: 545 (1974)

29. Klausner, H., and Heimberg, M.: Effect of adrenal cortical hormones on release of triglycerides and glucose by liver. Amer. J. Physiol., 212: 1239 (1967).

30. LeMarchand, Y., Singh, A., Assimacopoulos-Jeannet, F., Orci, L., Rouiller, C. and Jeanrenaud, B.: A role for the microtubular system in the release of very low density lipoproteins by perfused mouse livers. J. Biol. Chem., 248: 6862 (1973).

31. MacDonald, M., Neufeldt, N., Park, B. N., Berger, M., and Ruderman, N. Alanine metabolism and gluconeogenesis in the rat. Amer. J. Physiol., 23l: 619 (1976).

32. Marco, J., Calle, C., Roman, D., Diaz-Fierros, M., Villanueva, M. L., and Valverde, I.: Hyperglucagonism induced by glucocorticoid treatment in man. N. Engl. J. Med., 288: 128 (1973).

33. Mellanby, J., and Williamson, D. H.: $\beta$-Hydroxybutyrate. In: H. U. Bergmeyer: Methods of Enzymatic Analysis, p. 1836 (Academic Press, New York, 1974)

34. Mellanby, J, and Williamson, D. H.: Acetoacetate. In: H. U. Bergmeyer: Methods of Enzymatic Analysis, p. 1840 (Academic Press, New York, 1974).

35. Millward, D. J., Garlick, P. J., Nnanyelugo, D. O., and Waterlow, J. C.: The relative importance of muscle protein synthesis and breakdown in the regulation of muscle mass. Biochem. J., 156: 185 (1976).

36. Munck, A.: Glucocorticoid inhibition of glucose uptake by peripheral tissues: Old and new evidence, molecular mechanisms and physiological significance. Perspect. Biol. Med., 14: 265 (1971).

37. Pagliara, A. S., Karl, I., De Vivo, D. C., Feigen, R. D., and Kipnis, D. M. Hypoalaninemia: A concomitant of ketotic hypoglycemia. J. Clin. Invest., 51 ; 1440 (1972)

38. Passonneau, J. V.: Lactate. In: H. U. Bergmeyer: Methods of Enzymatic Analysis, p. 1468 (Academic Press, New York, 1974).

39. Passonneau, J. V., and Lowry, O. H.: Pyruvate. In: H. U. Bergmeyer: Methods of Enzymatic Analysis, p. 1452 (Academic Press, New York, 1974)

40. Patel, M. S., and Owen, O. E.: Development and regulation of lipid synthesis from ketone bodies by rat brain. J. Neurochem., 28: 109 (1977).
41. Pegorier, J. P., Ferré, P., and Girard, J. R.: The effects of inhibition of fatty acid oxidation in suckling newborn rats. Biochem. J., 166: 631 (1977).

42. Randle, P. J., Garland, P. B., Hales, C. N., and Newsholme, E. A.: The glucose fatty acid cycle: Its role in insulin sensitivity and the metabolic disturbance of diabetes mellitus. Lancet, 1 : 785 (1963).

43. Reaven, E. P., Kolterman, O. G., and Reaven, G. M.: Ultrastructural and physiological evidence for corticosteroid induced alterations in hepatic production of very low density lipoprotein particles. J. Lipid Res., 15: 74 (1974).

44. Roehrig, K. L., and Allred, J. B.: Direct enzymatic procedure for the determination of liver glycogen. Anal. Biochem., 58: 414 (1974).

45. Scott, J. L., and Engel, F. L.: The influence of the adrenal cortex and cold stress on fasting ketosis in the rat. Endocrinology, 53: 410 (1953).

46. Schoner, W., Haag, U., and Seubert, W.: Regulation of carbohydrate metabolism by cortisol, independent of the de novo synthesis of enzymes in rat liver. Hoppe-Seyler's Z. Physiol. Chem., 351: 1070 (1970).

47. Snell, $\mathrm{K}$ and Walker, D. G.: The adaptative behaviour of isoenzyme forms of rat liver alanine aminotransferases during development. Biochem. J., 128: 403 (1972).

48. Snell, K., and Walker, D. G.: Glucose metabolism in the newborn rat. Hormonal effect in vivo. Biochem. J., 134: 899 (1973).

49. Wieland, O.: Glycerol. In: H. U. Bergmeyer: Methods of Enzymatic Analysis, p. 1404 (Academic Press, New York, 1974).

50. Williamson, D. H.: Alanine. In: H. U. Bergmeyer: Methods of Enzymatic Analysis, p. 1679 (Academic Press, New York, 1974).

51. Williamson, D. H.: Regulation of the utilization of glucose and ketone bodies by brain in the perinatal period. In: R. A. Camerini-Davalos and H. S. Cole: Early Diabetes in early life, p. 195 (Academic Press, New York, 1975).

52. Wise, J. K., Hendler, R., and Felig, P. : Influence of corticosteroids on glucagon secretion in man. J. Clin. Invest., 52: 2774 (1973).

53. Yeung, D., Stanley, R. S., and Oliver, I. T. : Development of gluconeogenesis in neonatal rat liver: Effect of triamcinolone. Biochem. J., 105: 1219 (1967).

54. Intralipid, glycerol-free [composition: $10 \%(w / v)$ soybean oil emulsified with egg yolk phospholipids $1.2 \%$ (w/v)], kindly supplied by Vitrum, Stockholm, Sweden.

55. This research was supported by the Délégation Générale à la Recherche Scientifique et Technique (Grant 74-7-0020) and the Medical Research Council of Canada (MA-4782).

56. The authors express their gratitude to Dr. A. Kervran for performing the insulin determinations presented in this paper.

57. We are indebted to Ms. J. Boillot and to Mr. Chou-Nan Wei for their expert technical assistance in glucagon and amino acid analysis.

58. Requests for reprints should be addressed to: Dr. J. Girard, D. Sc., Laboratoire de Physiologie du Développement, Collège de France, 11 Place Marcelin Berthelot, 75231 Paris, Cedex 05 (France).

59. Received for publication May 10, 1977.

60. Accepted for publication October 18, 1977 